UDC 93/94

DOI https://doi.org/10.32838/2663-5984/2021/1.21

Okorokova $\boldsymbol{V} . \boldsymbol{V}$.

South Ukrainian National Pedagogical University named after K.D. Ushynsky

\title{
UTOPIA OF THE YAKOBIN DICTATORSHIP AND ITS FEATURES AS A SOCIO-POLITICAL PROJECT
}

The article is devoted to the study of one of the most pressing issues in world history - the manifestations of utopianism in the field of reform projects. The Jacobin dictatorship was chosen as the basis, which in the history of the Great French Revolution became the next stage of sociopolitical transformations.

The relevance and scientific novelty of the article are determined first of all by the effectiveness of the study of utopian issues in modern science, the importance of which is interdisciplinary. The latter is expressed in the fact that utopia as a product of social consciousness is the subject of study in general of the humanities in the field of scientific research, as it covers issues of philosophical, historical, culturological directions. Secondly, the level of study of the utopian characteristics of the Jacobin political regime, unfortunately, does not differ in the density of scientific developments, which in turn only increases the motivation to study it.

The article considers the main prerequisites for the coming to power of the Jacobin political movement, determines their socio-political image, the ideal of social order. At the same time, a parallel with utopian features is drawn. Attention is drawn to the influence of the enlightenment ideas of Western European society of the XVIII century on the formation of the socio-political ideal of the Jacobin political movement.

Utopian features have been identified, in particular, it is a utopia of the socio-political type, or as it is also called a utopia of politics. As an example, the ideas of one of the leading ideologues of the Jacobin movement Louis Antoine Saint-Just, in particular his definition of civil society, equality of all segments of society, and so on. The justifications of the Jacobins'cruel methods of fighting their opponents are also determined. The establishment of terror became a means of introducing its sociopolitical ideal in the country.

Key words: egalitarian utopia, utopia, utopia of politics, utopianism, Jacobin dictatorship.

Formulation of the problem. History has many plots of attempts at communitarian experiments, the implementation of a utopian project. A feature of this phenomenon is that utopia in its essence expresses the desires, dreams and social ideal of society of a particular time. It is inherent in public consciousness, it is an indicator of socio-political crisis processes. And only during periods of aggravation of these crises does utopia have the opportunity to move from the level of utopian thought to the category of utopianism, i.e. a reform project aimed at rebuilding society. It is in such periods, the points of bifurcation (according to synergetics), the utopian ideal as a product of social consciousness, the basis of which is the criticism of the socio-political structure existing in historical reality. In other words, in the words of one of the famous theorists of utopia E. Batalov, any socio-utopian project is a "mold" from the society that gave birth to it, a reverse projection of one historical era into another [1, p. 26]. Attention is drawn to those reformatory socio-political projects, programs, especially those that have been introduced into social reality. In this case, we are talking about the Jacobin dictatorship, the subject of which occupies a separate place in historical science.

Analysis of the last reports and publications. Unfortunately, the study of precisely the utopian features of this political movement in France during the Great French Revolution does not differ in the density of scientific works. In this case, only a few isolated works of such scientists as T. Medvedeva, L. Morshchina, O. Chudinov can be noted. For example, L. Morshchina calls the Jacobin political program an egalitarian utopia [6]. T. Medvedeva, exploring the phenomenon of utopian components in ideology, points out that the presence of the utopian in ideological constructions in the presence of appropriate sociopolitical prerequisites (transcendentally-oriented activism) creates the possibility of transforming ideological constructions into the ideology of social terror [5].

Setting goals. Based on the provisions of this problem noted above, the purpose of our study is to determine the utopian characteristics of the Jacobin socio-political program. 


\section{Objectives of the study:}

- explore the basic prerequisites for coming to power in France during the Jacobin revolution;

- to reveal the ideal of social order, which the Jacobins proposed in their program;

- to determine the utopian features of their sociopolitical innovations in society.

Presentation of the main research material. The history of the Jacobins coming to power contains the following points. On August 10, 1791, an uprising began in Paris, as a result of which the monarchy was destroyed. On October 1, 1791, a new Legislative Corps began work on the basis of the Constitution of 1791. In accordance with its decision, the division of communal lands and the confiscation of the lands of emigrants began. Abolished ownership of land by those who could not provide documents confirming the legality of ownership. However, in the National Convention (legislative body), a struggle broke out between the mountain (Jacobins) and the Girondins. On January 21, by decision of the National Convention, Louis XVI was executed, and the first republic was established in France. However, her position was very difficult: the economy was falling apart, the French armies were defeated by the interventionists, the country was engulfed in a network of rebellions. The Jacobins created the Committee of the Insurrection. The General Council of the Commune joined the movement. On May 31, 1793, the alarm again called the Parisians to arms. The convention had to listen to 14 demands of the rebels, among them the arrest of 22 Girondins, the leaders of the party.

On June 2, 1793, the National Guard and the armed people surrounded the Convention again. The convention has surrendered. 31 the Girondins had to leave its walls; for some time (before the trial) they were under house arrest. The Jacobins came to power. The French Revolution entered a new stage - the stage of the Jacobin dictatorship.

Interesting in this case is the opinion of P. Genife, who, analyzing the events of the French revolution, its preconditions and results, draws attention to the fact that it represented, at least in the minds of its participants, a rupture of the fabric of times, the renewal of human history, a rebirth through renunciation from the past and from tradition, and, finally, the foundation of the social order on principles derived from pure reason. In other words, she wanted to create "everything from nothing". The scientist argues that in France the revolutionary idea of tabula rasa led directly to terror, and if you take a general look at the path from 1789 to 1793 , you can admit that Burke was right, who predicted the French in 1790 a long road "through the darkness and chaos" [2].

Continuing the consideration of the issue of the Jacobins coming to power, it should be noted that their victory on a national scale was preceded by their victory over their opponents in the Jacobin Club; therefore, the regime they established was called the Jacobin dictatorship. It is also necessary to take into account the fact that in historical science one can find the use, in addition to the concept of "Jacobin dictatorship", also the concept of "Jacobin republic", about which there are disagreements among scientists. The problem in this case is rooted in the very essence of the Jacobin dictatorship: the republic is the external form of the organization of the Jacobin power, the dictatorship is the essence of the form of organization of the Jacobin power.

Gordon, studying the phenomenon of Jacobinism, came to the conclusion that the coming of the Jacobins to power as a result of the popular uprising of May 31 - June 2, 1793 was not just a stage, but a "revolution in the revolution" [3]. The social strata that emerged in 1793 introduced a special mentality to the revolutionary movement, which to their opponents, and partly to their descendants, could seem to be something pathological. Nevertheless, it was normal for these strata in an "abnormal" situation. Fully embodying the "situational logic", the logic of a unique historical situation, the aspirations of the "people of 1793" were basically familiar to the socalled lower ranks of French society, in many ways corresponded to their traditional worldview. Unaccustomed to society, truly anomalous for its history, was the degree of influence of the aspirations and moods of these lower classes on public opinion, on political leadership, on the course of revolutionary transformations.

The point is that behind the Jacobins stood a broad bloc of revolutionary democratic forces (the petty bourgeoisie, the peasantry, the rural and especially the urban poor). The leading role in this bloc was played by the so-called Montagnards (Robespierre, Saint-Just, Couton, etc.), whose speeches and actions reflected primarily the prevailing rebellious and egalitarian moods of the masses. It should be noted that the Jacobin party included a right wing led by Danton, a center led by Robespierre, and a left wing led by Marat (and after his death in the summer of 1793 by Ebert and Chaumette).

Like Rousseau, robespierres saw in morality a universal regulator of social relations, calling it "the soul of the republican system". The revolution seemed to them the culmination of the great battle between Good 
and Evil, which continued throughout the history of mankind. Only the victory of virtue, the robespierres believed, would solve all social problems. The set of virtues, which, according to Robespierre and his supporters, every "true republican" must have, was compiled on the basis of highly idealized ideas about the ancient states of Sparta and Rome. According to this abstract idea, the average "perfect" citizen does not have "unnecessary" needs, is ascetic, not burdened with an excess of knowledge, does not know pity for himself or for enemies, despises the feeling of pleasure and is ready to unconditionally sacrifice all his personal interests in the name of public [7].

Based on this, it becomes clear why the social program of the Jacobins was designed for the lower strata of the population, who became the driving forces of the revolution. The social ideal of the Jacobins is as follows: a society of small producers, where everyone owns land, a small workshop, a shop capable of feeding a family, and where a person directly exchanges his products with other people equal to him. The semantic core of the totality of political and legal views of the Jacobins is the provisions on state power, on the apparatus of the state, on the principles of its construction and functioning. There are three principles underlying the political union. First, the protection and provision of the natural rights of the citizen. Secondly, the right of every citizen to participate in legislation and government, due to natural equality and innate freedom of people. And third, the supremacy of the people in the state. In any situation, the people are entitled to decide their own destiny.

For example, one of the famous ideologues of the Jacobin political movement, Louis Antoine Saint-Just $[9 ; 10]$, proposes the creation of a civil community. The civil community is a social organism consisting of a legislator, a king and a sovereign. It is indivisible because a divided society ceases to be a society. All members of the community are equal; as soon as equality disappears, society ceases to exist, inequality is the same as force, and a society built on force is nothing but a gathering of savages. Because society can exist by being built on nature, a public community cannot know any laws other than the laws of nature. These laws are independence and preservation. Thus, the law is an expression of nature, not an expression of will [8, p. 102].

Laws, in his understanding, do not so much reflect as they create social relations. The Constitution for him is the very social structure of the country. The embodiment in the laws of social, social, moral norms of the relationship and behavior of citizens, should, according to the author, solve the most important tasks of forming a new worldview, lead to a moral revival of the nation, achieve harmony of interests of a person and a citizen, that is, private and public. The law is the most important part in the structure of political institutions. The government is called upon to set an example of law-abidingness and integrity.

Impeccable honesty, the strictest discipline and selfless courage are the hallmarks of the citizens of his state. This community is a vague specter of the outer structure of ancient society. The same strictest regulation of the life of citizens in the manner of Sparta, the same harsh regulations about the rights and obligations of the population. Every citizen of the community is obliged to report annually to the church on the use of his property in order to avoid excessive savings.

L. Morshchina, studying the utopianism of the Jacobin socio-political program, correlates it with the utopia of politics, explaining the following provisions. The utopia of politics places the desired ideal within the reach of man, makes it the goal of the struggle. Even if this struggle cannot end with the realization of the ideal, it, in any case, contributes to the destruction of the existing order, from the negation of which any utopia grows. This struggle begins something truly new, although its final result never coincides with what was intended. The fulfilled ideal ceases to be such, because it bears the stain of compromise and defeats that it suffered in a collision with reality. But as a result, the reality becomes different. The utopia of politics does not put forward any social ideals peculiar only to it. It is characterized rather by the special localization of these ideals than by their unconditional originality. We can say that the utopia of politics is the practical application of utopian thinking in the life of society [6].

The scientist argues that the revolutionary situation turned the idea of a "social contract" into a utopia of politics. The theoretical opposition of the two models of society traditionally - hierarchical and rational society as an association of free and equal people - has been replaced by a political conflict of opposing political programs. Utopia turned out to be involved in a real political struggle, but it did not cease to be a utopia, because as before, it proceeded from the opposition between reality and the ideal; not so much out of a determination to transform dominant relationships as out of a desire to transform - this time through revolution - bad relationships into good ones. Despite the fact that the Jacobins considered themselves Rousseau's students, they represented a completely different stage in the development of the idea - the stage of its practical implementation. The 
criticized reality is opposed here as an idea to society, which arises immediately as a result of the application of the political means proposed by the party. But the Jacobin leaders can hardly be considered pragmatists in the usual sense of the word. Their political realism - good or bad - has always been mixed with something that, in different connections and by different authors, is called utopianism.

The abovementioned fully explains the attempts by some modern scientists to define this kind of utopia. Namely, A. Lavrova understands the utopian component of political culture as a type of sociopolitical myth depicting in a systematic form an ideal social structure that is not realized in principle, or in a given historical period. One of its distinguishing features from other political myths is that, at least at critical moments in history, it is he who directly prompts people to action. Moreover, the scientist continues, we can say that political culture reflects the sociopolitical realities of the society in which it exists. On the other hand, one cannot fail to draw attention to the fact that political culture is thoroughly saturated with myths and, in essence, is utopian. Reflecting in the consciousness of the individual and in public morality, it rather speaks about the proper, and not about the real state of affairs. However, and this "must", the ideal is due to political, economic, social, religious and cultural realities [4, p. 51].

Such utopianism at that time was not alien, since for the social thought of the 18th century, which was looking for a replacement for traditional Christian morality, an increased interest in ethical problems was characteristic. As T. Medvedeva notes, JeanJacques Rousseau seeks to achieve an ideal "free" social order with the help of the idea of a "common will". However, in the political practice of the Jacobins, this ideal attitude was transformed into an ideology of terror. In political actions, program documents of revolutionaries, we can trace how elements of such utopianism stimulate the formation of the ideology of public violence [5].

The scientist establishes a direct connection between the utopian views of Rousseau and the ideology of terror during the Jacobin dictatorship, considering this phase of the revolution an attempt to implement his ideas. The idea of the common good as the embodiment of the common will, taken from Rousseau, was very often used in the speeches of the Jacobins. In the treatises of Saint-Just, the speeches of Robespierre, the connection between the elements of utopianism in the "Social Contract" by J.-J. Rousseau with the results of the revolution, which the Jacobins predicted after the victory. This naive belief in an ideal world, without a sober understanding of the possibility, turned in practice into terrorism of the Committee of Public Safety, which sought with an iron fist to remove everyone standing in the way of the exercise of power.

From this perspective, it is interesting to combine terror with the introduction of their own program points by the Jacobins. T. Medvedeva draws attention to the fact that by the end of their power the Jacobins' harsh methods of eliminating opponents were equal to the ideals of freedom and justice they proclaimed [5]. Namely, the scientist refers to the speeches of Robespierre, who repeatedly said in his speeches that revolutionary terror is only a temporary measure for building a state of popular sovereignty - otherwise there will be no victory of freedom over tyranny. But the ideologue of terror, having no ideological justification, was constantly being promoted. In his speech at the Convention, Robespierre said that at the moment when freedom seeks, apparently, the most brilliant triumph, the enemies of the fatherland are even more daring conspiracies. Justice and terror merged in Robespierre into one concept. As a result, Terror came to be seen as a manifestation of the highest virtue. Violence began to have a symbolic meaning, identifying with the noble goal of waiting for a bright future. That is, terror, violence is a necessary condition for the happiness of humanity, the achievement of virtue and equality. Thus, the implementation of Rousseau's utopia turned into a practice of bloody terror and violence. As a result, T. Medvedeva concludes that on the example of the Jacobin attempt to reorganize the social system, utopia has fully fulfilled its function, blowing up the existing order.

Conclusions. The Jacobin dictatorship may well be seen as an attempt to create an ideal society in accordance with the principles of some educational theories. It is important to note that the socio-political image of the Jacobins was built depending on the social ideal of that time, with different strata of the population, most of them the lower strata of society. At the time of the political struggle of the Jacobins for power, the participation of various segments of the population reaches its climax. It was this factor that determined the presence of utopian features, since the basis of any type of utopia is the criticism of the socio-political and economic spheres of society. On the basis of the latter, the utopian builds an example of an ideal social structure, which acts as an alternative and antipode to the existing one. Hence the ideas of prominent representatives of the Jacobin movement, its ideologists, about the reorganization of the 
social system, the change of social relations, etc. That is, we are talking about the fact that the utopianism of the Jacobin dictatorship was the result of sociopolitical and educational trends in the middle of the 18 'th century, among which the roots of the utopian ideal were ripening.

It is not for nothing in this regard that some scholars, as we have seen, attribute the utopia of the Jacobin socio-political program to the utopia of politics. So, indeed, given the pulsation of utopian thought in the history of society, which is expressed in a cyclical change of periods of decline / rise, in this case we are talking about just another peak. It is for this reason that it is appropriate to speak not just about utopia, but about utopia (attempts to introduce utopia into social reality), as well as about the design of certain types of utopia (in this case, the utopia of politics). And considering that utopia as a product of public consciousness reacts to any manifestations of the crisis, then in this case the coming to power of the Jacobins became quite conditioned, since, we repeat, their socio-political program expressed the ideas of the majority of the population, which became the driving force revolution.

\section{References:}

1. Баталов Э. В мире утопии: Пять диалогов об утопии, утопическом сознании и утопических экспериментах. Москва : Политиздат, 1989. 317 с.

2. Генифе П. Французская революция и Террор. Франиузский ежегодник 2000: 200 лет Франиузской револючии 1789-1799 г2. : Итоги юбилея. Москва : Эдиториал, 2000. C. 68-87. URL: http://annuaire-fr. narod.ru/statji/Genife-2000.html.

3. Гордон А. Иллюзии-реалии якобинизма. Речи. Трактаты / Л.А. Сен-Жюст. Санкт-Петербург, 1995. URL: http://larevolution.ru/Gordon2.html.

4. Лаврова А. Утопия и утопические компоненты политической культуры. Культура, личность, общество в современном мире: методология, опыт эмпирического исследования : ХІ Международная конференция, Екатеринбург, 19-20 марта 2008 г. Екатеринбург : Факультет политологии и социологии УГУ, 2008. Ч. 2. С. $50-53$.

5. Медведева Т. От утопии общественного договора к идеологии террора. Бренное и вечное : образы мифа в пространствах современного мира : материалы Всероссийской научной конференции, посвященной 10-летию философского факультета НГУ имени Ярослава Мудрого, 28-29 сентября 2004 г. Великий Новгород : НовГУ им. Ярослава Мудрого, 2004. URL: http://brennoe-i-vechnoe.narod.ru/04-57.html.

6. Морщихина Л. О принципах управления «идеального государства». Эгалитарная утопия якобинской диктатуры. Философия и практика управления и самоуправления : материалы 4-тых Педагогических чтений. Архангельск : Изд-во СГМУ, 2002. URL: http://www.docme.su/doc/1191481/o-principah-upravleniyaideal._nogo-gosudarstva-e-galitarnaya.

7. Морщихина Л. «Фрагменты республиканских установлений» (“Les Institutions republicaines. Fragments") А. Сен-Жюста как характерный пример утопического творчества XVIII века. URL: http://hrono.ru/statii/2003/utopia.html.

8. Окорокова В. Західноєвропейська утопія XVIII століття як приклад філософії історії епохи Просвітництва : хрестоматія. Одеса : Принт-студія «Абрикос», 232 с.

9. Сен-Жюст Л.А. О Природе, о Гражданском состоянии, о Гражданской общине, или Правила независимости управления. Речи. Трактаты. Санкт-Петербург : Наука, 1995. С. 251-277.

10. Сен-Жюст Л.А. Республиканские установления. Фрагменты. Речи. Трактаты. Санкт-Петербург : Наука, 1995. С. 277-319.

11. Чудинов А. Утопии века Просвещения : курс лекций. Москва : ИВИ РАН, 2000. 90 с.

\section{Окорокова В.В. УТОПІЯ ЯКОБІНСЬКОЇ ДИКТАТУРИ ТА ЇЇ РИСИ ЯК СОЦІАЛЬНО- ПОЛІТИЧНОГО ПРОЕКТУ}

Стаття присвячена дослідженню одного з актуальних питань всесвітньої історії - прояви утопізму у сфері реформаторських проєктів. За основу було обрано якобінську диктатуру, яка в історіі Великої франиузької револючї стала черговим етапом соиіально-політичних трансформацій.

Актуальність та наукова новизна статті визначаються, по-перше, ефективністю дослідження утопічної проблематики в сучасній науці, вагомості якій надає міждисииплінарний характер. Останнє виражається в тому, що утопія як продукт суспільної свідомості є предметом вивчення взагалі гуманітарної сфери наукових досліджень, оскільки охоплює питання філософського, історичного, культурологічного напрямів. По-друге, рівнем дослідженості утопічних характеристик саме якобінського політичного режиму, який, на жаль, не відрізняється густотою наукових розробок, щцо, зі свого боку, лише збільшує мотивацію до ї̈ вивчення. 
У статті розглядаються основні передумови приходу до влади якобінського політичного руху, визначається їхній соиіально-політичний образ, ідеал суспільного устрою. Водночас проводиться паралель з утопічними рисами. Звертається увага на вплив просвітницьких ідей західноєвропейського суспільства ХVIII століття на формування суспільно-політичного ідеалу якобінського політичного руху.

Визначено утопічні риси, зокрема йдеться про утопію соиіально-політичного типу, або, як ще ії називають, утопію політики. Як приклад наводяться ідеї одного із провідних ідеологів якобінського руху Луї Антуана Сен-Жюста, зокрема його визначення громадянської общини, про рівність усіх верств у суспільстві тощо. Визначаються також обтрунтування якобінців жорстоких методів боротьби зі своїми противниками. Встановлення терору стало засобом упровадження свого суспільно-політичного ідеалу у країні.

Ключові слова: егалітарна утопія, утопія, утопія політики, утопізм, якобінська диктатура. 